\title{
LEGENDA PULAU KEMARO : STUDI PANDANGAN PENGUNJUNG DAN HUBUNGANNYA DENGAN AYAT-AYAT KEIMANAN
}

\author{
John Supriyanto \\ Fakultas Ushuluddin dan Pemikiran Islam UIN Raden Fatah Palembang \\ johnsupriyanto_uin@radenfatah.ac.id
}

\begin{abstract}
This paper is directed to find out how the views of the visitors who come to the island of Kemaro and connect it with the verses of faith that exist in the Qur'an. As is known, Kemaro Island store legends and love stories between Prince Tan Bun An and Princess Siti Fatimah. In the legend, the island of Kemaro is believed to have been formed due to the death of princes and princesses who drowned in the Musi River as a result of saving their wealth. The view of the visitors who come to this island which will then be connected with the verses of faith-as it is in the Quran-for the Quran actually speaks of a legend. In principle, the verses of faith that exist in the Qur'an does invite humankind to always mentauhidkan God in all aspects; good for world life or religion. In substance, the verses of faith invite men to always believe in God; not associating with Him; and always worship and surrender only to Him. Therefore, the motives and intentions of the visitors who come to the island of Kemaro is intended for a vacation; not worship. The opposite happened with the Chinese community and Confucian believers who came to worship and pray for the souls of their ancestors or gods that they believed.
\end{abstract}

Key words: Legend, Kemaro Island, Verses of Faith.

\begin{abstract}
Abstrak : Tulisan ini diarahkan untuk mengetahui bagaimana pandangan para pengunjung yang datang ke Pulau Kemaro dan menghubungkannya dengan ayat-ayat keimanan yang ada dalam Alquran. Sebagaimana diketahui, Pulau Kemaro menyimpan legenda dan cerita cinta antara Pangeran Tan Bun An dan Putri Siti Fatimah. Dalam legenda tersebut, Pulau Kemaro dipercayai terbentuk karena kematian pangeran dan putri yang tenggelam di Sungai Musi akibat ingin menyelamatkan hartanya. Pandangan para pengunjung yang datang ke pulau inilah yang kemudian akan dihubungkan dengan ayat-ayat keimanan - sebagaimana yang ada di dalam al-Quran — untuk sebenarnya al-Quran berbicara tentang suatu legenda. Secara prinsip, ayat-ayat keimanan yang ada dalam al-Quran memang mengajak manusia untuk selalu mentauhidkan Allah dalam segala aspek; baik untuk kehidupan dunia atau agama. Dalam substansinya, ayat-ayat keimanan mengajak manusia untuk selalu percaya kepada Allah; tidak menyekutukan-Nya; dan selalu beribadah dan berserah diri hanya kepada-Nya. Karena itulah, motif dan niat para pengunjung yang datang ke Pulau Kemaro memang bertujuan untuk berlibur; bukan beribadah. Hal sebaliknya terjadi dengan komunitas Cina dan pemeluk agama Konghucu yang datang memang untuk memuja dan mendoakan arwah nenak moyang atau dewa yang mereka percayai.
\end{abstract}

Kata kunci : Legenda, Pulau Kemaro, Ayat-Ayat Keimanan 


\section{A. Pendahuluan}

Dalam ilmu sejarah, "legenda" (bahasa Latin: legere) dikenal sebagai cerita prosa rakyat yang dianggap oleh yang mempunyai cerita sebagai sesuatu yang benar-benar terjadi. Oleh karena itu, legenda sering kali dianggap sebagai "sejarah" kolektif (folk history). Walaupun demikian, karena tidak tertulis, maka kisah yang ada dalam legenda tersebut telah mengalami distorsi sehingga sering kali jauh berbeda dengan kisah aslinya. Secara ilmiah, kita bisa mengatakan bahwa legenda dapat berarti sebagai cerita rakyat zaman dahulu yang berkaitan dengan suatu peristiwa dan asal usul terjadinya suatu tempat. Kita bisa menyebut contohnya seperti Sangkuriang, Batu Menangis atau Legenda Pulau Kemaro.

Nama Pulau Kemaro memang sudah sangat dikenal baik oleh masyarakat kota Palembang sendiri atau bahkan dari luar Palembang. Pulau ini merupakan sebuah daratan kecil (delta) yang terdapat di tengah Sungai Musi, yang tidak jauh dari pusat Kota Palembang. Pulau Kemaro juga dijadikan sebagai tempat rekreasi yg cukup terkenal. Di tempat ini, terdapat sebuah klenteng Hok Tjing Rio yang menjadi tempat diadakan acara Cap go meh setiap Tahun Baru Imlek. Di Pulau Kemaro juga terdapat makam dari putri Palembang, Siti Fatimah. Menurut legenda setempat yang tertulis di sebuah batu di samping Klenteng Hok Tjing Rio, pada zaman dahulu, datang seorang pangeran dari Negeri Cina, bernama Tan Bun Ann.

Dalam cerita yang berkembang, Tan Bun An datang ke Palembang untuk berdagang. Ketika ia meminta izin ke Raja Palembang, ia bertemu dengan putri raja yang bernama Siti Fatimah. Ia langsung jatuh hati, begitu juga dengan Siti Fatimah. Merekapun menjalin kasih dan berniat untuk ke pelaminan. Tan Bun An mengajak sang Siti Fatimah ke daratan Cina untuk melihat orang tua Tan Bun Han. Setelah beberapa waktu, mereka kembali ke Palembang. Bersama mereka disertakan pula tujuh guci yang berisi emas. Sesampai di muara Sungai Musi Tan Bun han ingin melihat hadiah emas di dalam Guci-guci tersebut. Tetapi alangkah kagetnya karena yang dilihat adalah sayuran sawi-sawi asin. Tanpa berpikir panjang ia membuang guci-guci tersebut kelaut, tetapi guci terakhir terjatuh diatas dek dan pecah. Ternyata didalamnya terdapat emas. Tanpa berpikir panjag lagi ia terjun ke dalam sungai untuk mengambil emas-emas dalam guci yang sudah dibuangnya. Seorang pengawalnya juga ikut terjun untuk membantu, tetapi kedua orang itu tidak kunjung muncul. Siti Fatimah akhirnya menyusul dan terjun juga ke Sungai Musi.

Jumlah pengunjung yang datang baik pada hari biasa atau akhir pekan mencapai ratusan orang perhari. Pada malam perayaan Cap go meh, jumah pengunjung yang datang malah bisa 
mencapai ribuan. Data dari Pemerintah Kota (Pemkot) Palembang menyebutkan bahwa pengunjung yang datang ke Pulau Kemaro pada tahun 2017, dapat melebihi jumlah 30.000 orang. Banyaknya jumlah pengunjung ke tempat ini tentu saja tidak semuanya untuk merayakan cap go meh. Pada harihari libur dan akhir pekan, jumlah pegunjung yang datang untuk melihat lebih dekat kuburan pangeran Tan Bun An dan Siti Fatimah atau 'pohon cinta', juga berasal dari kalangan muslim.

Banyaknya pengunjung yang berwisata ke Pulau Kemaro, dan kisah cinta yang tragis dalam legendanya, menunjukkan bahwa ada persoalan penting yang menjadi daya tarik dan membuat para pengunjung pergi ke pulau ini; yaitu pandangan mereka terhadap legenda tempat ini; dan bagaimana pandangan tersebut dihubungkan dengan ayat-ayat keimanan yang ada dalam al-Quran. Persoalan pertama berkaitan dengan pandangan pengunjung terhadap Pulau Kemaro sebagai legenda wong Palembang; dan persoalan kedua berkaitan dengan ayat-ayat al-Quran sebagai titik tolak untuk melihat unsur keimanan dalam pandangan dari para pengunjung tersebut.

Sebagai suatu legenda, para pengunjung yang datang ke Pulau Kemaro dipastikan sudah memiilki informasi tentang ceritanya sehingga kita bisa menganggap bahwa mereka sudah memiliki “pandangan" tersendiri tentang Pulau Kemaro. Tetapi pandangan itu sendiri akan disesuaikan dengan "pesan-pesan" yang ada dalam al-Quran terutama untuk melihat persoalan yang lebih besar, yaitu apakah pandangan pengunjung itu tentang Pulau Kemaro sesuai atau tidak sesuai dengan ayat-ayat keimanan dari al-Quran.

Oleh karena itu, tulisan ini sangat penting dilakukan mengingat para wisatwan yang datang untuk melihat Pulau Kemaro, sebagai legenda dan cerita lokal masyarakat Palembang, perlu mempertahankan unsur keimanan mereka sebagai seorang muslim terutama dengan menjadikan ayatayat keimanan dalam al-Quran sebagai pedomannya. Penelitian ini sendiri sangat bermanfaat karena dapat menjadi informasi tentang pandangan umat Islam terhadap pulau kemaro dan menjaga nilainilai keimanan mereka dari hal-hal yang tidak sesuai dengan nilai-nilai keimanan.

Penelitian ini dilakukan di wilayah Kota Palembang, tepatnya di Pulau Kemaro yang berada di aliran Sungai Musi. Penelitian ini merupakan penelitian lapangan dengan objek kajiannya adalah para pengunjung yang datang ke Pulau Kemaro. Secara metodologis, penelitian ini adalah deskriptif kualitatif. Data dianalisis dengan menggunakan pendekatan kualitatif yang lebih ditekankan pada fenomenologi. Pengumpulan data meliputi studi dokumentasi yang berdasarkan dari literatur-literatur yang ada. Kemudian dengan survei lapangan melakukan wawancara terhadap pengunjung untuk mendapatkan informasi mengenai pandangan dan motif mereka yang datang ke Pulau Kemaro. Setelah semua data terkumpul kemudian dilakukan analisisis untuk menjabarkan atau mengidentifikasi pandangan dan motif mereka datang ke Pulau Kemaro sebagai sebuah legenda dan 
tempat wisata di kota Palembang. Data yang akan digunakan diperoleh dari situasi apa adanya tanpa adanya intervensi dari pihak peneliti. Pengumpulan data dilakukan oleh peneliti secara langsung dengan memasuki situasi lapangan.

\section{B. Folklor, Legenda dan Mitos}

Salah satu bentuk kebudayaan yang dimiliki oleh masyarakat kita adalah folklor atau cerita rakyat. Tradisi lisan ini diwariskan secara turun-temurun dan jejaknya masih dapat kita temukan pada masa sekarang. Tradisi lisan ini juga bisa beragam bentuknya. Seperti yang dikemukakan oleh Danandjaja, bahwa bagian budaya yang disebut folklor itu dapat berupa bahasa rakyat, ungkapan tradisional, teka-teki (pertanyaan tradisional), sajak dan puisi rakyat, cerita prosa rakyat, seperti mite, legenda, dan dongeng (lelucon dan anekdot), nyanyian rakyat, teater rakyat, permainan rakyat, kepercayaan, seni rupa rakyat, musik rakyat dan gerak isyarat.

Folklor yang berkembang dan diwariskan secara turun-temurun dalam suatu masyarakat, bukan berarti tidak memiliki nilai guna (fungsi). Folklor memiliki fungsi yang sangat mendasar (penting) bagi masyarakat pendukungnya. Tradisi lisan melukiskan kondisi fakta mental tradisi masyarakat yang mendukungnya, simbol identitas bersama masyarakatnya sehingga menjadi simbol solidaritas dari masyarakatnya, dan menjadi alat legitimasi bagi keberadaan suatu kolektif, baik sebuah marga, masyarakat maupun suku bangsa. Atau seperti yang dikemukakan oleh Danandjaja (1983) yang mengutip pendapat dari Bascom menyatakan bahwa bentuk-bentuk folklor mempunyai fungsi sebagai berikut : 1) sebagai sistem proyeksi; 2) sebagai alat pengesahan budaya; 3) sebagai alat paedagogik; dan 4) sebagai alat pemaksa berlakunya norma-norma masyarakat dan pengendalian masyarakat.

Perkembangan folklor dalam kehidupan masyarakat, merupakan perwujudan dari usaha dan cara-cara kelompok tersebut dalam memahami serta menjelaskan realitas lingkungannya, yang disesuaikan dengan situasi alam pikiran masyarakat di suatu zaman tertentu. Alam pikiran masyarakat yang dipandang sebagai lahan paling subur bagi berkembangnya pemikiran seperti itu, menurut Peursen (1976), adalah alam pikiran mistis. Alam pikiran mistis sangat menjiwai (mendasari) tradisi lisan masyarakat Indonesia sejak zaman dahulu sampai sekarang. Cara masyarakat menjelaskan atau memahami realitas seperti di atas, bukan merupakan suatu kesengajaan untuk mengacaukan fakta dengan khayalan, tetapi memang merupakan suatu cara dalam menangkap realitas sesuai dengan alam pikiran mereka. 
Sementara itu, dalam Kamus Besar Bahasa Indonesia, "legenda” disebut sebagai cerita rakyat pada zaman dahulu yang ada hubungannya dengan peristiwa sejarah. Istilah "legenda hidup" dapat juga diartikan dengan tokoh cerita yang masih hidup.

Secara sederhana, "legenda" selalu dikaitkan dengan cerita yang dipercaya oleh beberapa penduduk setempat sebagai sesuatu yang benar-benar terjadi. Pada kaitan ini, legenda tidak pernah lepas dari nama dan tempat. Pulau Kemaro, sebagai representasi dari legenda Pangeran Tan Bun An dan Puteri Siti Fatimah, mengambil tempat di aluan Sungai Musi dalam bentuk tanah daratan atau delta. Legenda juga disebut juga 'cerita rakyat' pada zaman dahulu yang ada hubungannya dengan peristiwa sejarah. Dengan makna yang lebih khusus, menurut Emeis, legenda adalah cerita kuno yang setengah berdasarkan sejarah dan yang setengah lagi berdasarkan angan-angan. Bahkan menurut William R. Bascom, legenda adalah cerita yang mempunyai ciri-ciri yang mirip dengan mitos, yaitu dianggap benar-benar terjadi, tetapi tidak dianggap suci. Begitu juga menurut Hooykaas, legenda adalah dongeng tentang hal-hal yang berdasarkan sejarah yang mengandung sesuatu hal yang ajaib atau kejadian yang menandakan kesaktian.

Dalam pengertian di atas, legenda memang selalu dikaitkan dengan mitos atau mite; yaitu cerita prosa rakyat yang menceritakan kisah berlatar masa lampau, mengandung penafsiran tentang alam semesta dan keberadaan makhluk di dalamnya, serta dianggap benar-benar terjadi oleh yang empunya cerita atau penganutnya. Dalam pengertian yang lebih luas, mitos lebih mengacu kepada cerita tradisional.

Pada umumnya mitos juga menceritakan terjadinya alam semesta, dunia dan para makhluk penghuninya, bentuk topografi, kisah para makhluk supranatural, dan sebagainya. Mitos dapat timbul sebagai catatan peristiwa sejarah yang terlalu dilebih-lebihkan, sebagai alegori atau personifikasi bagi fenomena alam, atau sebagai suatu penjelasan tentang ritual. Mereka disebarkan untuk menyampaikan pengalaman religius atau ideal, untuk membentuk model sifat-sifat tertentu, dan sebagai bahan ajaran dalam suatu komunitas.

Dengan demikian, dalam dua istilah yang digunakan ini, cerita rakyat tentang Pulau Kemaro tidak dapat disebut mitos; tetapi lebih dekat sebagai legenda. Ia mengandung sebuah informasi sejarah yang sekalipun di dalamnya terjadi pembiasan, namun bersumber dari sejarah lokal.

\section{Deskripsi Ayat-Ayat Keimanan dalam Al-Quran}

Pokok utama masalah keimanan al-Quran memang berkaitan dengan prinsip keimanan secara umum. Islam meyakini bahwa keimanan kepada Allah adalah bagian penting dari lima keimanan lain 
yaitu iman kepada malaikat, kitab suci, utusan atau rasul, hari akhir dan takdir. Prinsip yang disebut dengan rukun iman dan tertera banyak dalam al-Quran ini membuat masalah keimanan kepada Allah menjadi sangat penting. Para teolog menjelaskan bagaimana keimanan kepada Allah berhubungan dengan keimanan kepada hal lain seperti kepada sifat dan perbuatan Allah. Beberapa tema umum dari ayat-ayat keimanan memang dengan mudah dapat kita temukan dalam al-Quran. Tema-tema itu berbicara tentang kewajiban beriman kepada Allah, larangan berbuat syirik dan menyekutukan Allah, keimana kepada hari kiamat, takdir dan sebagainya.

Beriman kepada Allah adalah merupakan perintah langsung yang diberikan kepada orangorang yang beriman. Bahkan perintah iman itu juga dilakukan untuk para utusan Allah dan kitabkitab-Nya. Implikasi dari perintah ini, maka orang yang tidak melaksanakan keimanan tersebut termasuk dalam kategori orang-orang yang sesat. Dalam QS. Al-Baqarah [2]; 255 disebutkan bahwa Allah memperkenalkan diri-Nya sebagai Tuhan yang memiliki seluruh yang ada di langit dan bumi. Juga digambarkan bahwa Dia adalah satu-satunya yang mampu memberikan pertolongan.

Deskripsi yang sangat lengkap juga diungkapkan dalam QS. Al-Hasyr; 22-24 yang menyebutkan bahwa Allah adalah Tuhan yang mengetahui segala alam gaib dan nyata; bersifat kasih dan sayang, raja dan pencipta serta yang memiliki nama-nama yang mulia. Gambaran ini membuktikan bahwa perintah untuk beriman kepada Allah bukan saja disebutkan secara harfiyah, tapi juga diuraikan melalui penyebutkan kekuasaan Allah yang maha besar

Selain perintah untuk beriman kepada Allah, al-Quran juga menyebutkan adanya larangan menyekutukan Allah dengan apapun atau yang dikenal dengan syirik. ${ }^{1}$ Dalam pandangan Ibn Qayyim al-Jawzi, syirik dibagi menjadi dua bagian; syirik besar dan kecil. ${ }^{2}$ Dalam QS. An-Nisa; 48 dikatakan bahwa syirik adalah dosa besar yang tidak akan diampuni oleh Allah. Tetapi justru Allah akan mengampuni dosa-dosa besar selain syirik. Kenyataan ini juga menambahkan pemahaman bahwa dosa besar dari perbuatan syirik itu dikarenakan ia berlawanan dengan prinsip-prinsip ketauhidan manusia kepada Allah. Dengan kata lain, prinsip tauhid yang harus dipegang oleh manusia sebagaimana yang diiinginkan oleh Allah harus mampu menafikan perbuatan syirik. Pada sisi ini, kita dapat memahami betapa Allah membenci apapun perbuatan syirik karena dianggap tidak sesuai dengan prinsip-prinsi-Nya.

QS. Luqman ayat 13 juga menyebutkan adanya pesan untuk menghindari perbuatan syirik yang harus disampaikan oleh orang tua kepada anaknya. Luqman al-Hakim, yang namanya disebut

\footnotetext{
1 Menurut kamus, syirik berasal dari bahasa Arab al-syirk yang berarti memberikan bagian yang sedikit atau banyak dalam zat dan makna. Secara istilah, syirik artinya perbuatan yang mengandung unsur menyandarkan pada sesuatu makhluk selain Allah. Orang yang melakukannya disebut musyrik; musyrikun. Ibn Qayyim, Madarij al-Salikin, Dar al-Kitab al-Arabi. hal. 45.
} 
dalam al-Quran sebagai sosok manusia yang soleh, memaparkan kepada anaknya bahwa syirik adalah perbuatan zalim yang sangat besar.

Cerita seperti tokoh Lukman al-Hakim, Qarun, serta Ya'juj dan Ma'juj, memang ada disebutkan dalam al-Quran. Pada sisi ini, prinsip keimanan mengharuskan setiap muslim untuk percaya sepenuhnya tentang apa saja yang disebut dalam al-Quran. Dalam Q. Al-Baqarah; 147 disebutkan bawha "Kebenaran itu adalah dari Tuhanmu, sebab itu jangan sekali-kali kamu Termasuk orang-orang yang ragu”.

Mitos atau cerita yang terjadi pada masa dulu, digunakan al-Quran melalui kata asatir alawwalin; yang berarti cerita-cerita orang terdahulu. Kata ini ada pada QS. Al-Qalam; 14 yang berbunyi, "Apabila dibacakan kepadanya ayat-ayat Kami, ia berkata: "(Ini adalah) dongengdongengan orang-orang dahulu kala." Juga pada QS. An-Nahl; 24 disebutkan, " Dan apabila dikatakan kepada mereka "Apakah yang telah diturunkan Tuhanmu?" mereka menjawab: "Dongengdongengan orang-orang dahulu".

Sebagai kitab suci, Al-Quran menceritakan beberapa kisah tentang Ashabul Kahfi, Qarun, Lukman al-Hakim dan lain-lain adalah sebagai bukti adanya kekuasaan Allah dan menjadi pelajaran (ibrah) bagi manusia. Termasuk juga kejadian-kejadian besar seperti yang terjadi pada bangsa 'Ad dan bangsa Tsamud menunjukkan betapa Allah mampu melakukan sesuatu yang tidak bisa dilakukan oleh manusia. Dengan kata lain, mitos atau legenda yang menghubungkan suatu kejadian kepada manusia sebagai adikuasa, ditolak al-Quran karena bertentangan dengan prinsip tauhid akan kekuasaan Allah. Hal inilah yang diuraikan al-Quran dalam QS. Yunus; 106, "Dan janganlah kamu menyembah apa-apa yang tidak memberi manfaat dan tidak (pula) memberi mudharat kepadamu selain Allah; sebab jika kamu berbuat (yang demikian), itu, Maka Sesungguhnya kamu kalau begitu Termasuk orang-orang yang zalim".

Mitos karena itu bisa terjadi karena adanya ritual yang dilakukan oleh manusia untuk menghindari musibah pada dirinya. Dari sinilah muncul upacara seperti sesajen atau ruwatan sebagai "penawar"; padahal ini juga dilarang dalam Qs. Al-Hadid: 26; bahwa apa yang terjadi dan menimpa manusia, maka hal itu sebenarnya sudah ada dalam ketetapan Allah.

Mitos atau melakukan sesuatu yang berkaitan dengan mitos, karena itu bertentangan dengan tauhid rububiyyah dan uluhiyyah. Dalam tauhid rububiyyah, diyakini bahwa Allah adalah satusatunya Tuhan, Pencipta, Penguasa dan Pengatur alam semesta. Segala yang terjadi tidak lain atas kehendak dan kekuasaan-Nya. Karena itulah, al-Quran mendorong manusia untuk melakukan ritual hanya untuk Allah termasuk berdo'a, meminta pertolongan atau meminta perlindungan. 


\section{Pandangan Pengunjung Pulau Kemaro dalam Relasi Tauhid}

\section{Relasi Tauhid dalam Niat}

Dari sisi motif dan tujuan pengunjung yang datang ke Pulau Kemaro, kita tidak melihat adanya unsur syirik apalagi melakukan ibadah yang bertentangan dengan ajaran Islam. Hampir semua pengunjung mengatakan bahwa tujuan mereka datang ke Pulaun Kemaro adalah untuk jalanjalan atau berlibur. Hal ini dapat kita fahami bahwa sebagai salah satu tempat wisata yang lokasinya dekat dengan kota, Pulau Kemaro menjadi tempat tujuan yang cukup disenangi.

Dalam Islam, niat termasuk kategori amaliyah qolbiyah atau sikap hati yang hanya Allah SWT dan pribadi masing-masing yang tahu soal niat dan motif dalam berbuat atau beribadah. Secara bahasa, niat adalah keinginan dalam hati untuk melakukan suatu tindakan. Memang secara istilah, tidak terdapat definisi khusus untuk kata niat. Karena itu, banyak ulama yang memberikan makna niat secara bahasa, semisal Imam Nawawi yang mengatakan niat adalah bermaksud untuk melakukan sesuatu dan bertekad bulat untuk mengerjakannya."

Ada beberapa faktor yang bisa kita berikan terkait tempat wisata ini menjadi menarik yang berasal dari hasil wawancara dengan pengunjung itu sendiri; yaitu (1) transportasi sungai yang cukup murah dan menyenangkan; 2) gambar foto pagoda yang dipajang dalam webnsite dan laman-laman pribadi di internet; serta 3) pengalaman para pengunjung yang sudah pernah datang. Faktor-faktor ini menurut penulis, menjadi bukti betapa sebagai tempat wisata, Pulau Kemaro dikunjungi bukan karena legendanya saja, tetapi karena lokasinya yang dekat dan media tarnsportasinya yang cukup mudah.

Dari data ini, kita bisa mengatakan bahwa motif kedatangan para pengunjung yang ingin melihat langsung bagaimana legenda Pulau Kemaro, memang tidak memiliki tendensi syirik kepada Allah. Hal ini dibuktikan dari hasil wawancara kepada beberapa pengunjung tentang hal-hal lain; misalnya tanggapan mereka tentang pohon cinta, doa kepada kubur dn sebagainya. Dari aspek ini juga, pernyataan pengunjung membuktikan ketiadaan unsur syirik yang menjadi motif mereka.

\section{Relasi Tauhid dalam Peristiwa Luar Biasa}

Iman kepada kejadian dan peristiwa besar yang luar biasa dan berada di luar jangkauan akal manusia memang termasuk dalam prinsip iman kepada Allah. Peristiwa yang luar biasa itu dapat masuk dalam kategori mu'jizat, karomah, ma'unah atau irhas. Mu'jizat atau mukjizat adalah terambil dari kata bahasa Arab a'jaza yang berarti "melemahkan atau menjadikan tidak mampu". 
Menurut istilah, mu'jizat berarti sesuatu yang luar biasa yang terjadi dalam diri nabi atau rasul Allah SWT. Mukjizat bertujuan untuk membuktikan kenabian atau kerasulan seorang nabi atau rasul Allah SWT yang tidak dapat ditiru oleh siapa pun dan untuk melemahkan segala macam usaha dan alasan orang kafir dalam menentang islam, dan menyeru kepada umat agar percaya akan keesaan Allah. Adanya mukjizat diakui sendiri oleh Allah Swt dalam QS. Asy-Su'ara': 4 yang berbunyi : “Jika kami kehendaki niscaya Kami menurunkan kepada mereka mukjizat dari langit, maka senantiasa kuduk-kuduk mereka tunduk kepadanya." Oleh karena itu, iman kepada mukjizat menjadi wajib sebab berhubungan dengan eksistensi kenabian dan risalah ketuhanan. Orang yang mengingkari keberadaan mukjizat berarti ia telah keluar dari sistem kepercayaan yang saling berhubungan; Tuhan, Malaikat dan Nabi. Selain mukjizat, al-Quran juga memberikan informasi adanya karomah; yaitu keadaan yang luar biasa yang diberikan Allah kepada orang-orang yang dicintainya.

Karomah berasal dari bahasa arab yang berarti "kemuliaan, keluhuran, dan anugerah". Menurut Kamus Besar Bahasa Indonesia, istilah karomah sama dengan keramat; artinya suci atau dapat mengadakan sesuatu diluar kemampuan manusia biasa karena ketaqwaanya kepada Tuhan. Menurut ulama sufi, karamah berarti keadaan luar biasa yang diberikan Allah SWT kepada para wali-Nya. Wali ialah orang yang beriman, bertakwa, dan beramal shaleh kepada Allah SWT. Baik mukjizat atau karomah bahkan maunah dan irhas, semuanya menunjukkan adanya peristiwa yang terjadi pada diri seseorang yang tidak dapat dilakukan oleh manusia lain dengan tujuan agar timbul kepercayaan kepada orang yang memiliki kelebihan tersebut. Hal ini mengindikasikan bahwa Islam mempercayai adanya semacam "kekuatan" yang berada di luar kemampuan manusia. Oleh karena itu, keimanan kepada "kekuatan" tersebut tidak boleh bertentangan atau menyalahi keimanan kepada Tuhan.

Sebagai sebuah legenda, peristiwa munculnya kuburan Pangeran Tan Bun An dan Siti Fatimah di Pulau Kemaro memang tidak dapat dibuktikan secara historis. Tidak ada saksi bahkan informasi yang sifatnya historis yang memberitakannya bagaimana tiga orang yang tenggelam itu kemudian memunculkan gundukan tanah yang dianggap sebagai kuburan. Juga masih tidak jelas apakah yang muncul itu tanah delta ataukah tanah kuburan. Legenda Pulau Kemaro, karena itu lebih banyak berkembang dalam tradisi lisan penduduk lokal. Di sinilah relasi antara persoalan keimanan kepada Tuhan dengan kekuatan non-lagis yang ditampilkan dalam peristiwa Pulau Kemaro.

Kita bisa melihat bahwa relasi keimanan yang disampaikan al-Quran terhadap berbagai peristiwa alam dan kejadian yang luar biasa, secara mutlak kembali kepada Allah sang penguasa tunggal. Alam bahkan manusia, tidak memiliki kekuatan kecuali melalui kekuatan-Nya. Informasi al- 
Quran ini kemudian menjadi filter dalam keimanan seorang muslim; sehingga mereka tidak boleh menyakini kekuatan alam itu secara parsial; tanpa campur tangan Tuhan.

Dari hasil wawancara dengan pengunjung yang datang ke Pulau Kemaro, memang terdapat indikasi adanya kepercayaan masyarakat terhadap 'peristiwa' legenda Pulau Kemaro. Bahwa ada Pangeran Tan Bun An, putri Siti Fatimah dan pengawalnya dengan bukti 'kuburan' atau gundukan tanah, dipercayai pengunjung sebagai kebenaran historis. Tetapi jika dihubungkan dengan peristiwa luar biasa, makam Tan bun An, Siti Fatimah dan pengawalnya dianggap tidak memiliki kekhususan sebagaimana informasi al-Quran; dan karena itu banyak para pengunjung yang juga tidak meyakininya.

Legenda Pulau Kemaro, karena itu tidak menjadi bagian dalam sistem kepercayaan masyarakat Islam, khususnya di Palembang. Kunjungan masyarakat ke pulau ini lebih sekedar berlibur tanpa harus ikut percaya dengan legenda yang ada. Salah satu kasus yang cukup menarik adalah keberadaan pohon cinta yang cukup mengundang syirik. Pohon ini dikatakan memiliki 'kekuatan' yang dapat membuat cinta menjadi abadi. Beberapa pasangan muda-mudi kemudian menuliskan namanya di batang pohon.

Berdasarkan informasi yang didapat langsung dari pengunjung, mereka sebenarnya tidak terlalu yakin bahkan cenderung tidak tahu bagaimana pohon cinta itu dianggap memiliki kekuatan. Justru terungkap dari pengunjung kritikan kepada orang yang menuliskan namanya sebagai perbuatan yang buruk dan menimbulkan kerusakan lingkungan. Dari informasi ini juga diketahui bahwa 'kekuatan' pohon cinta ternyata berasal dari sumber yang tidak jelas dan bertujuan hanya untuk menarik pengunjung.

Jadi kita menemukan semacam relasi keimanan yang cukup menarik, bahwa sekalipun para pengunjung mengetahui peristiwa kejadian Pulau Kemaro, tetapi mereka tidak melihatnya sebagai peristiwa yang luar biasa. Kita dapat memahami ini karena informasi munculnya Pulau Kemaro juga tidak jelas dan kurang dipercaya. Sebagai cerita lisan, bahkan dikemas dengan informasi modern dan motif pariwisata, Pulau Kemaro menjadi tujuan berlibur atau wisata. Tidak ada motif ibadah dalam kunjungan tersebut. Berbeda dengan ritual yang dilakukan oleh pengunjung dari etnis Cina, para pengunjung muslim tidak pernah meyakininya sebagai peristiwa luar biasa yang wajib mereka percayai.

\section{Relasi Tauhid dalam Ritual dan Doa}

Pulau Kemaro selain memang dijadikan wisata ruhani bagi kalangan etnis Cina dengan mengunjungi makam Tan Bun An dan kelenteng atau pagoda; juga pernah dikunjungi oleh masyarakat Islam keturunan Arab yang yakin bahwa di pulau ini ada makam Habib Ahmad al-Idrus. 
Pada perayaan Cap Go Meh, kalangan Tionghoa menyalakan dupa, berdoa di altar bahkan melakukan sesembahan kepada dewa atau arwah yang mereka yakini; sementara kalangan muslim keturunan Arab menziarahi makam Habib Ahmad pada waktu perayaan Ziarah Kubro. Ritual keagamaan yang dilakukan dengan cara ziarah kubur, doa dan sesembahan ini, menarik perhatian kita karena melibatkan dua agama yang berbeda; Budha/Konghucu dan Islam.

Dalam Islam, ziarah kubur diartikan dengan mendatangi kuburan, mendoakan orang yang berada di dalam kuburan agar dia diampuni oleh Allah SWT. Ziarah kubur sering disebut sebagai "nasehat" bagi orang yang masih hidup sebab akan membuatnya teringat kepada Allah. Dalam ziarah kubur ini juga banyak pendapat dan perbedaan pandangan dari para ulama terkait dengan relasi keimanan yang ada. Relasi keimanan yang bisa dihubungkan dalam ziarah kubur disebabkan karena banyak hal; misalnya karena prinsip utama Islam yang melihat bahwa selain Allah tidak ada yang mampu memberikan kebaikan atau keburukan; selain Allah tidak ada doa yang layak dipanjatkan; bahkan selain Allah tidak boleh ada ibadah dilakukan. Relasi keimanan inilah yang menjadi alasan sikap pro-kontra bahwa dalam ziarah kubur tidak ada unsur yang bertentangan dengan iman; atau dalam ziarah kubur ada unsur yang mengandung syirik.

Perilaku para pengunjung yang datang ke Pulau Kemaro, memang tidak langsung pada pelaksanaan ritual ziarah kubur. Kita bisa mengatakan bahwa ziarah kubur bukanlah menjadi tujuan utama para pengunjung. Seperti informasi sebelumnya, mereka yang datang ke Pulau Kemaro justru ingin menikmati liburan dan sekedar berjalan-jalan. Jadi dugaan awal; ziarah kubur di Pulau Kemaro tidak menarik perhatian para pengunjung.

Hasil wawancara penulis dengan pengunjung, memang hampir seluruhnya melihat bahwa ziarah kubur secara umum dibolehkan. Ini tidak lepas dari pemahaman mereka bahwa ziarah kubur adalah ritual yang disukai Nabi. Tetapi bagi mereka yang datang ke Pulau Kemaro, lalu berziarah di kuburan yang ada di dalam kelenteng lalu berdoa kepada kuburan, maka ini dianggap sebagai hal yang salah bahkan syirik. Para pengunjung sepakat bahwa meminta sesuatu kepada kuburan di Pulau Kemaro ini adalah perbuatan syirik yang dapat menyebabkan iman menjadi hilang.

Kita bisa melihat bahwa relasi keimanan yang berkaitan dengan ziarah kubur di Pulau Kemaro ini dikarenakan "ahli kubur" yang masih kurang jelas; apakah Tan Bun An, Siti Fatimah, pengawalnya atau Habib Ahmad? Bahkan, kuburan yang berada di dalam kelenteng (yang notabene merupakan rumah ibadah agama Konghucu) menjadi sebab tidak bolehnya mereka melakukan ibadah. Dengan kata lain, kita menemukan adanya persoalan penting terkait informasi dan posisi kuburan yang akan di ziarahi. Dalam pengandaian; jika ketiga kuburan itu berada di luar kelenteng, maka dimungkinkan para pengunjung akan menziarahinya. 
Tetapi, ketidakjelasan informasi siapa yang ada di dalam kuburan tersebut juga yang menyebabkan para pengunjung tidak mau membacakan doanya. Sangat berbeda dengan pengunjung dari etnis Cina yang melakukan ziarah dan mendoakan arwah leluhur mereka di depan altar di dalam kelenteng. Dengan kenyataan ini, sangat mungkin pandangan bahwa ziarah kubur dan beroda kepada kuburan yang ada di Pulau Kemaro masuk dalam kategori syirik kepada Allah.

Jelas bahwa relasi keimanan yang dimiliki oleh para pengunjung dengan ritual ziarah kubur yang ada di Pulau Kemaro muncul karena adanya pelaksanaan serta rumah ibadah milik agama lain yang membuat pengunjung muslim tidak boleh ikut bergabung di dalamnya. Hal ini didukung juga dari ketidakjelasan siapa yang ada di kuburan tersebut; apakah orang Islam atau bukan. Bahkan, kita bisa mengatakan bahwa seandainya makam Habib Ahmad al-Idrus memang ada di Pulau Kemaro, maka ziarah kubur mungkin akan dilakukan oleh para pengunjung.

\section{Relasi Tauhid dalam Makna Legenda}

Pulau Kemaro sebagai sebuah legenda, memang tidak dapat dipisahkan dari sejarah kota Palembang. Letaknya yang berdekatan dengan kota, membuat pulau ini memiliki posisi yang sangat strategis. Pada masa kesultanan Palembang Darussalam, pulau ini dijadikan sebagai benteng yang sangat kokoh dari ancaman penjajahan Belanda. Juga pada masa pemberontakan PKI, pulau ini juga dijadikan tempat penampungan tahanan-tahanan PKI.

Sisi sejarah yang melekat pada Pulau Kemaro memang tidak muncul sebanyak sisi legendanya. Gambaran Pulau Kemaro sebagai tempat kuburan dari Tan Bun An dan Siti Fatimah, lebih banyak diketahui dan didengar orang. Bahkan, pagoda di pulau ini menjadi tujuan utama untuk dilihat oleh para pengunjung. Pulau Kemaro dengan demikian menjadi sangat identik dengan legendanya; ketimbang sejarahnya.

Sebagai legenda, cerita yang melekat pada Pulau Kemaro juga didengar dan disampaikan secara luas. Buku-buku bacaan dari cerita rakyat, website dan laman pribadi dalam blog atau facebook; memuat cerita legenda Pulau Kemaro yang luar biasa. Sehingga kita bisa mengambil semacam pernyataan bahwa hampir rata-rata masyarakat yang mendengar kata Pulau Kemaro pasti akan menghubungkannya dengan cerita Tan Bun An dan Siti fatimah, guci dan emas yang ada di dasar Sungai Musi, kuburan atau tanah gundukan serta pohon cinta.

Berdasarkan wawancara penulis dengan beberapa pengunjung, didapat informasi bahwa mereka memang mengetahui Pulau Kemaro karena cerita atau legendanya. Bahkan yang sangat menarik bagi mereka adalah 'peninggalan' Tan Bun An dan Siti Fatimah berupa gundukan atau kuburannya. 
Relasi tauhid yang dapat kita buktikan adalah bagaimana pengunjung melihat peristiwa matinya Tan Bun An dan Siti fatimah serta pengawalnya yang kemudian membentuk suatau kuburan atau gundukan tanah. Memang, secara langsung ada juga pengunjung yang mengakui bahwa gundukan tanah (yang sekarang ada di dalam kelenteng) sebagai kuburan. Tetapi apakah di dalam kuburan itu ada Tan Bun An dan Siti Fatimah, sebagian besar tidak mengetahuinya.

Karena legenda, kepercayaan masyarakat kepada persitiwa Pulau Kemaro adalah kepercayaan yang tidak mendasar. Berbeda dengan 'Bukit Puncak Sekuning' yang memang menjadi kuburan bagi raja-raja kerajaan Sriwijaya dan adanya arca Budha yang ditemukan. Pulau Kemaro tidak menunjukkan informasi sejarah yang historis; dalam artian tidak ada peninggalan khusus yang saling berkait dengan sejarah lain di Palembang.

Dari relasi ini, kita bisa mengatakan bahwa pengunjung yang datang ke Pulau Kemaro lebih disebabkan karena rasa penasaran kepada isi cerita yang tragis (yaitu emas yang terbuang dan pelaku yang mati di dalam sungai) dari pada ingin membuktikan kepercayaannya kepada legenda. Jadi, pada sisi ini, sekalipun para pengunjung percaya kepada legenda Pulau Kemaro, penulis bisa mengatakan bahwa kepercayaan itu tidak membuat mereka merasa yakin bahwa ceritanya benar. Bahkan, Pulau Kemaro tidak menjadi kisah legenda yang menarik disebabkan informasi yang tidak terlalu jelas.

\section{Relasi Tauhid dalam Pohon Cinta}

Dalam komplek Pulau Kemaro, memang terdapat pohon cinta yang dikatakan menjadi lambang cinta suci Tan Bun An dan Siti Fatimah. Dari sisi fisik, pohon yang memiliki cabang banyak ini memang mengundang orang untuk mengakuinya sebagai pohon aneh. Karena itu, banyak tulisan dan komentar dari para pengunjung yang mereka tulis tentang pohon ini.

Informasi tentang pohon cinta memang ditampilkan dalam dua hal; pertama, bahwa siapa saja yang menuliskan namanya dan nama pasangannya akan menjadi pasangan yang abadi seperti Tan Bun An dan Siti Fatimah; kedua, siapa yang mencoret-coret atau merusak pohon ini maka dia akan sakit atau mati. Tidak ada informasi lain yang disampaikan oleh mereka yang pernah datang ke Pulau ini kecuali dua hal ini.

Keberadaan pohon cinta sebagai pohon 'keramat' di Pulau Kemaro juga tidak selamanya dibenarkan oleh penduduk pulau itu. Salah satu penduduk yang menjual makanan dan minuman mengatakan bahwa cerita kekeramatan pohon cinta adalah isu yang dikatakan oleh para pemandu wisata. Bahkan, menurutnya, perilaku pengunjung yang mencoret-coret nama mereka di batang pohon membuat pohon cinta ini menjadi kotor dan rusak. Karena itulah, dibangun pagar pembatas supaya tidak ada pengunjung yang bisa mencoretnya. 
Dari hasil wawancara dengan para pengunjung, didapat informasi bahwa mereka sama sekali tidak percaya kalau pohon cinta dapat menyebabkan orang lain menjadi sakit atau mati. Ketidakpercayaan mereka berdasarkan argumen bahwa memang hanya Allah yang bisa membuat orang sakit atau mati. Bahkan cinta yang abadi tidak dilakukan dengan cara membuat nama di batang pohon.

Informasi ini setidaknya membuat kita mengerti bahwa para pengunjung yang datang ke Pulau Kemaro memang bukan untuk melihat pohon cinta. Tetapi dikarenakan posisi pohon cinta berada di belakang Pagoda dan menjadi satu bagian dengan Pulau Kemaro, maka otomatis pengunjung akan melihat dan berada di sekitarnya. Hal ini juga dimungkinkan karena pengunjung yang mengetahui pohon cinta justru berasal dari informasi lisan yang tersebar dari mulut ke mulut. Apalagi situs berita resmi seperti Tribun Palembang dan Newsantara pernah menampilkan pohon cinta dengan judul yang cukup menggugah orang untuk datang melihatnya.

Dengan kata lain, kita dapat melihat bahwa dari aspek tauhid, pengunjung yang datang melihat pohon cinta ini memang tidak yakin bahwa pohon ini dapat menyebabkan cinta menjadi abadi atau malah mati. Bagi mereka, keberadaan pohon cinta yang dari sisi namanya sangat menarik (baca : cinta) membuat mereka ingin melihatnya secara langsung. Padahal, setelah mereka mengetahuinya secara kasat mata, mereka mengatakan bahwa bentuk pohon tersebut biasa saja. Jadi, kita bisa mengatakan bahwa relasi tauhid yang berkaitan dengan pohon cinta ini disebabkan karena bentuknya yang aneh, ditambah dengan pagar kayu yang berada di sekelilingnya membuat pengunjung atau orang yang mendengar cerita pohon cinta ini berpikiran yang macam-macam. Dengan kata lain, timbul persepsi yang berbeda dari seseorang atau pengunjung yang seolah-olah membenarkan 'kekuatan' pohon ini. Inilah yang menyebabkan nilai-nilai tauhid kepada Allah akan berkurang dan dikhawatirkan akan menjadi syirik.

\section{E. Kesimpulan}

Beberapa hal yang menjadi kesimpulan dalam tulisan ini dapat disampaikan bahwa secara prinsip, ayat-ayat keimanan yang ada dalam al-Quran memang mengajak manusia untuk selalu mentauhidkan Allah dalam segala aspek; baik untuk kehidupan dunia atau agama. Dalam substansinya, ayat-ayat keimanan mengajak manusia untuk selalu percaya kepada Allah; tidak menyekutukan-Nya; dan selalu beribadah dan berserah diri hanya kepada-Nya. Dihubungkan dengan kehidupan manusia di dunia, ayat-ayat keimanan juga mengharuskan manusia percaya bahwa segala kekuatan dan kekuasaa hanya milik Allah. Tidak ada yang mampu menandingi dan melebihi kekuasan-Nya. 
Sebagai salah satu tujuan wisata di kota Palembang, Pulau Kemaro memang menarik perhatian para pengunjung yang tertarik dengan cerita antara Tan Bun An dan Putri Siti Fatimah. Kisah cinta dari anak dua bangsa ini ditampilkan sebagai menu utama Pulau Kemaro yang disampaikan secara lisan melalui cerita dari mulut ke mulut, situs resmi milik Pemerintah, kantor berita atau laman pribadi online milik seseorang. Hampir seluruh media informasi tersebut ternyata menyampaikan cerita tragis yang kurang jelas. Ketidakjelasan ini telihat dari tidak adanya nama kerajaan, baik di Cina atau Palembang, serta tahun kejadian. Bahkan kemunculan pulau ini juga menjadi tidak jelas dengan kemunculan tanah gundukan atau kuburan. Inilah yang memuat legenda Pulau Kemaro terebar lebih banyak dalam bentuk lakon cerita; bukan narasi peristiwa. Akibatnya, banyak para pengunjung yang datang ke Pulau Kemaro lebih bertujuan untuk menghilangkan rasa penasarannya terhadap tanah gundukan atau kuburan dari pasangan manusia itu atau hanya sekedar mengisi waktu libur saja.

Relasi keimanan yang terlihat dari motif serta niat, perilaku dan pandangan para pengunjung yang datang ke Pulau Kemaro, tidak berdampak pada masalah syirik. Tidak ada pengunjung yang datang ke Pulau Kemaro sengaja untuk berdoa atau berziarah ke kuburan Tan Bun An kecuali dari etnis Cina atau pemeluk agama Konghucu. Bagi pengunjung muslim, peristiwa yang terjadi dalam legenda Pulau Kemaro bisa saja terjadi; dan bisa saja tidak. Sebab, bagi mereka, kalau memang Allah berkuasa membuat Pulau Kemaro atau memunculkan gundukan tanah yang ada di dalam Pulau Kemaro, maka itu bisa saja terjadi.

Karena itulah, motif dan niat para pengunjung yang datang ke Pulau Kemaro memang bertujuan untuk berlibur; bukan beribadah. Hal sebaliknya terjadi dengan komunitas Cina dan pemeluk agama Konghucu yang datang memang untuk memuja dan mendoakan arwah nenak moyang atau dewa yang mereka percayai.

\section{DAFTAR PUSTAKA}

Basrowi Sukidin, Metode Penelitian Kualitatif Perspektif Mikro (Grounded Theory, Fenomenologi, Etnometodology, Etnograhy, Dramaturgi, Interaksi Simbolik, Hemeneutik, Konstruksi Sosial, Analisis Wacana, dan Metodologi Refleksi. Insan Cendikia, Surabaya, 2002

Bogdan, Robert C. And Steven J. Taylor, Introduction to Qualitative Research Methods: A Phenomenological Approach in the Social Sciences, alih bahasa Arief Furchan, John Wiley and Sons, Usaha Nasional, Surabaya, 1992

Sugiyono, Metode Penelitian Administrasi, Bandung, Alfabeta, 2013

Emzir, Metodologi Penelitian Pendidikan: Kuantitatif an Kualitatif. Rajawali Press, Jakarta, 2008

Margono S., Metodologi Penelitian Pendidikan, Rineka Cipta, Jakarta, 2010

Miles dan Huberman, Qualitative Data Analysis: A Sourcebook of New Methods. Sage Publication, Inc. London, 1984

Toshihiko Izutsu, Konsep Kepercayaan dalam Teologi Islam, Yogyakarta: Tiara Wacana, 1994 Muhammad Syahrur, al-Islam wa al-Iman; Manzumat al-Qiyam, Dar al-Ahali li al-Tiba'ah wa al- 
Nashr wa al-Tawzi’; 1996

Wanaputri, Diah Ayu; Kajian Ornamen Pagoda Cina Di Pulau Kemaro Palembang Sumatera Selatan; Fakultas Bahasa dan Seni Universitas Negeri Yogyakarta, 2015

Anisah, Ali Imron dan Muhammad Basri dalam Tinjauan Historis Tentang Fungsi Pulau Kemaro Di Palembang Sumatera Selatan Tahun 1965-2012; Jurnal Pendidikan Seajrah dan Penelitian Sejarah; tp, 2013

Maharani,Dwi, Makna Pariwisata Pulau Kemaro menurut Pengunjung dan Perilaku Komunikasinya, Jurnal Kajian Komunikasi Vol 2, No. 1 (2014); Fakultas Komunikasi, Unpad.

http://id.wikipedia.org/wiki/Kesultanan_Palembang

Travel Club, Majalah, Edisi 175/Agustus 2006/Th.XVIII/hal. 92.

http://nationalgeographic.co.id/berita/2014/01/pulau-kemaro-kisah-pengantin-malang-dan -pohonjodoh

http://palembang-tourism.com/destinasi-376-pulau-kemaro-kota-palembang.html.

http://newsantara.com/destinasi/kisah-cinta-bulan-purnama-cap-go-meh-yang -melegenda-di-pulaukemaro.

http://download.portalgaruda.org/article.php?article=287308\&title=TinjauanHistoris Tentang PulauKemarodiPalembangSumateraSelatanTahun1965-2012.

http://palembang-tourism.com/destinasi-376-pualu-kemaro-kota-palembang.html. http://palembangpos.com/ziarah-kubro-ke-pulau-kemaro.

http://www.antaranews.com/berita/608489/pengunjung-cap-go-meh-di-pulau-kemarodiperkirakan-30000-orang. 